\title{
Analisis Trading Volume Activity dan Bid-Ask Spread Setelah Stock Split
}

\author{
Luh Ade Wahyu Merthadiyanti ${ }^{1}$ \\ Gerianta Wirawan Yasa ${ }^{2}$ \\ ${ }^{1,2}$ Fakultas Ekonomi dan Bisnis Universitas Udayana (Unud), Bali, Indonesia \\ e-mail: merthadiyanti@gmail.com
}

\begin{abstract}
ABSTRAK
Penelitian ini bertujuan untuk mengetahui apakah terdapat peningkatan trading volume activity dan penurunan bid-ask spread setelah dilakukan stock split. Populasi pada penelitian ini adalah seluruh perusahaan di BEI yang melakukan stock split dimana berjumlah 234 perusahaan. Jumlah sampel yang diambil sebanyak 53 perusahaan, dengan metode non probability sampling, khususnya purposive sampling. Teknik pengambilan data yaitu teknik dokumentasi dari Bursa Efek Indonesia. Metode analisis yang digunakan adalah analisis paired sample t-test. Berdasarkan hasil analisis ditemukan bahwa terdapat peningkatan TVA setelah stock split yang menunjukan bahwa minat investor mengalami peningkatan karena harga saham yang rendah dan terdapat penurunan bid-ask spread yang menunjukan bahwa likuiditas perdagangan saham mengalami peningkatan.
\end{abstract}

Kata kunci: Trading volume, bid-ask, split

\section{ABSTRACT}

This study aims to determine whether there is an increase in TVA and a decrease in the bidask spread after a stock split is carried out. The population in this study were all companies on the IDX that conducted a stock split in which there were 234 companies. The number of samples taken was 53 companies, with non probability sampling methods, specifically purposive sampling. Data collection techniques are documentation techniques from the Indonesia Stock Exchange. The analytical method used is the analysis of paired sample $t$ test. Based on the results of the analysis it was found that there was an increase in TVA after the stock split which showed that investor interest had increased due to low stock prices and a decrease in bid-ask spreads which showed that stock trading liquidity had increased.

Keywords: Trading volume, bid-ask, split

\section{PENDAHULUAN}

Pasar modal merupakan salah satu sarana untuk melakukan investasi. Pasar modal memungkinkan investor melakukan diversifikasi investasi, membentuk portofolio yang sesuai dengan risiko yang bersedia mereka tanggung dan tingkat pengembalian (return) yang diharapkan. Bagi investor, tujuan investasi melalui pasar modal adalah untuk memperoleh tingkat pengembalian (return) yang lebih besar dibandingkan dana yang ditanamkannya. Return tersebut dapat berupa capital gain maupun dividen (Halim \& Hidayat, 2000). Investor menentukan dan 
memilih pada perusahaan mana mereka akan menanamkan modalnya dengan tujuan memperoleh keuntungan maksimal melalui permintaan dan penawaran saham yang terjadi.

Salah satu faktor yang mempengaruhi besarnya permintaan dan penawaran saham adalah tingkat harga saham tersebut. Nilai harga saham yang dinilai terlalu tinggi oleh pasar menyebabkan jumlah permintaan akan berkurang. Sebaliknya, bila pasar menilai terlalu rendah, jumlah permintaan akan meningkat. Tingginya harga saham tersebut dapat mengurangi kemampuan investor untuk membeli saham tersebut, sehingga harga saham yang tinggi akan menurun sampai tercipta posisi keseimbangan yang baru (Pramana, 2012).

Menurut Mulatsih (2009) suatu pasar bereaksi terhadap suatu informasi untuk mencapai harga keseimbangan yang baru adalah merupakan hal yang penting. Hal itu disebabkan karena informasi akan mengakibatkan perubahan harga, sehingga return juga akan berubah, begitu juga persepsi investor akan berubah dan pengambilan keputusan investasi juga akan berubah. Informasiinformasi yang dipublikasikan ini dapat berupa informasi yang hanya mempengaruhi harga sekuritas dari perusahaan yang mempublikasikan informasi tersebut. Informasi ini umumnya berhubungan dengan peristiwa yang terjadi di perusahaan emiten (corporate action). Corporate action merupakan aktivitas emiten yang berpengaruh terhadap jumlah saham yang beredar dan berpengaruh terhadap harga saham di pasar (Darmadji \& Fakhruddin, 2012). Pada umumnya corporate action secara langsung maupun tidak langsung akan dapat mempengaruhi harga sekuritas yang beredar, komposisi kepemilikan sekuritas, pergerakan harga sekuritas dan lain sebagainya 
sehingga akan berpengaruh terhadap kepentingan stakeholders dan khususnya shareholder (Lianawati, 2015).

Para pelaku di pasar modal sangat memerlukan informasi yang dapat mempengaruhi naik turunnya harga saham, karena hal ini dapat mempengaruhi pengambilan keputusan investor dalam membeli atau menjual saham (Bodie, Z., Kane \& Marcus, 2005). Informasi corporate action yang dapat dimanfaatkan para pelaku pasar salah satunya adalah stock split. Stock split merupakan suatu aktivitas yang dilakukan perusahaan yang telah go public dalam rangka meningkatkan jumlah saham yang beredar dengan melakukan pemecahan jumlah lembar sahamnya menjadi lebih banyak dengan tujuan agar harga sahamnya dirasa cukup murah atau terjangkau oleh investor sehingga diharapkan penjualan sahamnya bisa meningkat dan sahamnya bisa dimiliki oleh banyak investor (Brigham \& Gapenski, 1994). Beberapa kebijakan yang termasuk dalam corporate action selain stock split diantaranya adalah right issue, pembagian saham bonus, pembagian dividen, Initial Public Offering (IPO), dan Additional Listing seperti private placement, konversi saham baik dari warrant, rights ataupun obligasi (Pramana, 2012). Stock split adalah memecah selembar saham menjadi n lembar saham. Harga per lembar saham baru setelah stock split adalah sebesar $1 / \mathrm{n}$ dari harga sebelumnya. Dengan demikian, sebenarnya stock split tidak menambah nilai dari perusahaan atau dengan kata lain stock split tidak mempunyai nilai ekonomis.

Menurut Hartono (2014), kemungkinan perusahaan melakukan stock split adalah berhubungan dengan likuiditas harga sekuritas. Alasan perusahaan melakukan stock split umumnya supaya harga saham tidak terlalu tinggi, sehingga akan meningkatkan likuiditas perdagangannya. Penelitian menurut Mishra (2006), 
Chakraborty (2012), Waweru \& Mwendwa (2012), Yan (2012), Pooja (2013), Ford, H.Nguyen, \& T. Nguyen (2012) juga menyatakan bahwa terjadi peningkatan likuiditas. Dengan adanya stock split, harga saham menjadi tidak terlalu tinggi sehingga investor merasa aman bertransaksi saham dengan harga yang terjangkau (Alon \& Kronlund, 2009). Copeland (1979) menemukan hal yang sebaliknya dengan alasan ini, yaitu likuiditas pasar akan semakin rendah setelah stock split, yaitu volume perdagangan akan menjadi rendah dibanding sebelumnya, biaya transaksi broker akan meningkat dan bid-ask spread (selisih harga bid yang diajukan oleh pembeli dan harga ask yang diminta oleh penjual) juga lebih tinggi dari sebelumnya. Sejauh ini banyaknya peristiwa stock split yang terjadi di pasar modal menurut data di BEI sampai saat ini telah terjadi 234 peristiwa stock split. Dalam kurun waktu tiga tahun yaitu tahun 2015 sampai 2017 semakin banyak perusahaan yang beramai-ramai untuk melakukan stock split yaitu sejumlah 54 peristiwa stock split. Dilihat dari data yang menunjukan semakin banyak ketertarikan perusahaan untuk melakukan stock split maka banyaknya peristiwa stock split di pasar modal memberikan indikasi bahwa stock split merupakan alat yang penting dalam praktik pasar modal dimana peristiwa stock split dapat memengaruhi efek perusahaan atau keputusan investasi pemodal, karena menyebabkan terjadinya perubahan nilai nominal saham, nilai pasar saham, dan jumlah saham yang beredar.

Menurut Khomsiyah \& Sulistyo (2001) menyatakan bahwa alasan dilakukannya stock split adalah untuk mencapai optimal range harga saham sehingga dapat menciptakan pasar yang lebih luas. Leung et al (2005) mengatakan 
bahwa apabila harga pre-split tinggi, maka stock split semakin menguatkan kebenaran akan motif tersebut. Harga saham yang rendah akan membuat para investor membelinya sehingga dengan meningkatnya minat investor maka akan meningkatkan volume perdagangan saham. Keuntungan yang didapat oleh perusahaan dengan meningkatnya volume perdagangan saham yaitu jumlah saham yang beredar lebih banyak sehingga modal yang didapat perusahaan akan terus bertambah karena investor beramai-ramai untuk berinvestasi dan perusahaan lebih mudah melakukan aksi korporasi lainnya untuk menambah modal perusahaan. Volume perdagangan yang besar mencerminkan bahwa investor menggemari saham tersebut sehingga saham cepat diperdagangkan dan pada akhirnya akan meningkatkan likuiditas saham. Tingkat likuiditas saham dapat dilihat dari adanya perubahan volume perdagangan yang diproksikan melalui trading volume activity (TVA) dan perubahan bid-ask spread. Apabila TVA meningkat dan bid-ask spread suatu saham lebih rendah, hal ini menunjukkan bahwa minat investor dan tingkat likuiditas saham tersebut meningkat.

Brigham \& Gapenski (1994) menyatakan bahwa stock split merupakan suatu fenomena yang masih diperdebatkan dan menjadi teka-teki dalam bidang ekonomi. Hal ini terlihat dari adanya ketimpangan antara teori dan praktik. Secara teoritis, stock split hanya kebijakan untuk menambah jumlah lembar saham yang beredar dengan tidak menambah kesejahteraan para investor. Stock split juga tidak mempunyai nilai ekonomis karena tidak menambah nilai dari perusahaan (Horner \& Wachowicz, 1997). Menurut Bechmann \& Raaballe (2007) menganggap bahwa kebijakan stock split hanyalah mempercantik saja dan tidak mempengaruhi 
kekayaan pemegang saham, jumlah lembar saham menjadi semakin banyak akan tetapi dengan harga saham semakin murah. Namun dalam praktiknya, beberapa bukti empiris seperti penelitian yang dilakukan oleh Mulyani \& Purba (2011), penelitian Sidqi, dkk. (2017), penelitian Trijunanto (2016) menyatakan bahwa peristiwa stock split menyebabkan meningkatnya volume perdagangan atau meningkatnya likuiditas akibat harga yang lebih menarik bagi investor. Ini menunjukan bahwa stock split dapat menambah kesejahteraan para investor karena dengan rendahnya harga saham maka daya tarik dan kemampuan investor untuk berinvestasi menjadi meningkat sehingga akan meningkatkan volume perdagangan saham dan nantinya return yang diharapkan akan meningkat.

Fenomena lainnya yaitu, menurut berita Kontan.co.id, emiten beramai-ramai melakukan stock split mulai dari sektor pertambangan, sektor swasta, dan sektor perbankan salah satunya yaitu PT Bank Rakyat Indonesia Tbk (BBRI) dan PT Bank Mandiri Tbk (BMRI). Tak mau ketinggalan, PT Bank Negara Indonesia Tbk (BBNI) memiliki rencana serupa tahun depan. Menurut data di BEI juga memperlihatkan hal yang sama, mulai tahun 2015 sampai sekarang peristiwa stock split yang terjadi semakin meningkat yaitu lebih dari 10 peristiwa stock split telah terjadi, sedangkan tahun 2015 kebawah masih sedikit perusahaan yang melakukan stock split bahkan kurang dari 5 peristiwa stock split yang terjadi dalam setahun. Kinerja Indeks Harga Saham Gabungan (IHSG) pada akhir tahun dari tahun 2015 sampai 2017 juga menunjukan peningkatan setiap tahunnya, dimana IHSG pada akhir tahun 2015 sebesar 4.593,01, pada akhir tahun 2016 sebesar 5.296,71, dan pada akhir tahun 2017 sebesar 6.355,65. Peningkatan IHSG 
inilah yang menyebabkan harga saham terus naik sehingga membuat para emiten beramai-ramai melakukan stock split.

Alasan perusahaan untuk melakukan corporate action berupa stock split dapat dijelaskan oleh dua teori, yaitu signaling theory dan trading range theory. Forjan \& McCorry (1998) menyebutkan bahwa Signaling Theory berkaitan dengan informasi private yang dimiliki manajer dalam mengambil keputusan keuangan yang digunakan sebagai sinyal dari perusahaan kepada investor. Marwata (2001) yang meneliti stock split berdasarkan signalling theory menyatakan bahwa stock split berisi informasi yang ditujukan kepada investor mengenai prospek peningkatan return masa yang akan. Peningkatan return tersebut diprediksikan sebagai sinyal mengenai laba jangka pendek dan jangka panjang. Kebijakan stock split dianggap sebagai sinyal yang diberikan oleh manajemen kepada publik bahwa perusahaan memiliki prospek bagus di masa depan. Perusahaan yang memiliki kondisi fundamental kurang terpercaya tidak akan dapat menyamai sinyal yang dikirim oleh perusahaan dengan kondisi fundamental yang terpercaya (Bhattacharya \& Dittmar, 2001). Selain return saham, likuiditas saham juga bisa menjadi tujuan stock split. Teori yang menjelaskan hubungan antara likuiditas perdagangan saham dengan motivasi perusahaan melakukan stock split adalah trading range theory. Trading range theory adalah mengarahkan harga saham pada interval harga tertentu yang tidak terlalu mahal atau tidak melebihi harga optimal saham perusahaan tersebut (Setociputro, 2010). Copeland (1979) menyatakan bahwa alasan dilakukannya stock split adalah untuk mencapai optimal range harga saham agar dapat memudahkan para investor kecil untuk membeli sejumlah saham sehingga akan menimbulkan naiknya 
jumlah pemegang saham. Gejala yang ditimbulkan dari harga pasar saham yang terlalu tinggi akan menyebabkan likuiditas saham tersebut untuk diperdagangkan menjadi rendah, sehingga satu corporate action yang dapat dilakukan manajemen adalah dengan melakukan stock split. Harga saham yang rendah setelah split diharapkan dapat meningkatkan daya beli investor terhadap saham tersebut sehingga berimbas pada peningkatan volume perdagangan dan dapat meningkatkan likuiditasnya (Waelan, 2009).

Berdasarkan hal tersebut maka dapat ditarik suatu kesimpulan sementara bahwa untuk melihat apakah peristiwa stock split akan meningkatkan minat investor dan likuiditas suatu saham karena harga saham tidak terlalu tinggi maka akan ditunjukan dengan adanya perubahan volume perdagangan saham dan bidask spread setelah stock split. Volume perdagangan saham merupakan tingkat permintaan dan penawaran terhadap saham suatu perusahaan. Volume perdagangan yang besar mencerminkan bahwa investor menggemari saham tersebut sehingga saham cepat diperdagangkan dan pada akhirnya akan meningkatkan likuiditas saham. Perubahan volume perdagangan diukur dengan TVA, TVA merupakan perbandingan antara jumlah saham yang diperdagangkan pada waktu tertentu dengan jumlah saham perusahaan yang beredar pada periode tertentu. Semakin besar nilai TVA maka bisa dinterprestasikan semakin banyak volume saham yang diperdagangkan.

Selain TVA, tingkat likuiditas saham dapat dilihat dari adanya perubahan bid-ask spread. Bid price merupakan harga beli tertinggi dimana investor bersedia untuk membeli saham, sedangkan ask price merupakan harga jual terendah 
dimana investor bersedia untuk menjual sahamnya. Bid-ask spread merupakan selisih antara tawaran harga jual terendah dan harga beli tertinggi pada akhir jam perdagangan atas suatu jenis saham di BEI. Apabila bid-ask spread suatu saham lebih rendah, hal ini menunjukkan bahwa tingkat likuiditas saham tersebut meningkat.

Berdasarkan uraian latar belakang diatas, maka permasalahan dalam penelitian ini dapat dirumuskan sebagai berikut 1) Apakah terdapat peningkatan trading volume activity setelah stock split?; 2) Apakah terdapat penurunan bid-ask spread setelah stock split?

Berdasarkan dari permasalahan yang telah diuraikan, maka tujuan dari penelitian ini adalah 1) Untuk mengetahui ada tidaknya peningkatan trading volume activity setelah stock split; 2) Untuk mengetahui ada tidaknya penurunan bid-ask spread setelah stock split.

Penelitian ini memiliki dua manfaat, yaitu pertama manfaat teoritis dimana penelitian ini diharapkan dapat memberikan tambahan ilmu pengetahuan mengenai stock split. Kedua, manfaat praktis penelitian ini diharapkan dapat membantu para investor dalam hal pengambilan keputusan berhubungan dengan penginvestasian dalam perusahaan yang melakukan stock split.

Dasar penelitian dalam penelitian ini merupakan teori signal yang berarti perilaku manajemen perusahaan dalam memberikan petunjuk atau sinyal kepada investor terkait prospek perusahaan untuk masa depan. Sinyal ini berupa informasi mengenai apa yang sudah dilakukan oleh manajemen untuk merealisasikan keinginan pemilik (Brigham \& Houston, 2014). Mason \& Shelor 
(1998) menyatakan bahwa stock split menunjukan sinyal yang positif dari manajer perusahaan kepada pemegang saham karena adanya asimetri informasi antara manajer dan pemegang saham, sehingga diperlukan suatu sinyal yang menunjukan suatu prospek perusahaan yang baik bagi investor yang belum mengetahuinya. Salah satu jenis informasi yang dikeluarkan oleh perusahaan yang dapat menjadi sinyal bagi pihak di luar perusahaan, terutama bagi pihak investor adalah laporan tahunan. Informasi yang diungkapkan dalam laporan tahunan dapat berupa informasi mengenai laporan keuangan dan informasi non-akuntansi yaitu informasi yang tidak berkaitan dengan laporan keuangan (Hartono, 2010).

Menurut Copeland (1979), stock split yang dilakukan emiten memerlukan biaya yang harus ditanggung dan hanya perusahaan yang mempunyai prospek yang bagus yang dapat menanggung biaya tersebut. Kondisi inilah yang akan menyebabkan pasar bereaksi positif. Perusahaan yang tidak mempunyai prospek yang bagus dan mencoba memberikan sinyal lewat stock split, bukanlah stock split yang akan meningkatkan harga sekuritasnya, tetapi menurunkannya apabila pasar cukup canggih untuk mengetahuinya bahwa perusahaan tersebut tidak mempunyai prospek kinerja yang bagus atau dengan kata lain tidak mampu menanggung biaya yang timbul jika perusahaan akan melakukan stock split. Adanya biaya pemecahan, yang termasuk didalamnya biaya transfer agen untuk proses sertifikat dan biaya lainnya dapat menimbulkan kerugian bagi perusahaan, sedangkan bagi pemegang saham tidak terdapat kerugian akibat dilakukan stock split. Kondisi inilah yang akan menyebabkan pasar bereaksi positif terhadap peristiwa stock split. Perusahaan yang memiliki prospek yang bagus akan mampu 
menarik daya tarik investor untuk berinvestasi sehingga dapat meningkatkan kesejahteraan para investor.

Trading range theory adalah mengarahkan harga saham pada interval harga tertentu yang tidak terlalu mahal atau tidak melebihi harga optimal saham perusahaan tersebut (Setociputro, 2010). Copeland (1979) menyatakan bahwa alasan dilakukannya stock split adalah untuk mencapai optimal range harga saham agar dapat memberikan kemudahan kepada investor kecil untuk membeli sejumlah saham maka akan menimbulkan kenaikan jumlah pemegang saham.

Trading volume activity merupakan penjualan dari setiap transaksi yang terjadi di bursa saham pada saat waktu dan saham tertentu, dan merupakan salah satu faktor yang juga memberikan pengaruh terhadap pergerakan harga saham. Trading volume activity digunakan untuk mengukur volume perdagangan dengan membandingkan jumlah saham yang beredar pada periode tertentu dengan jumlah saham yang beredar pada waktu tertentu.

Bid price merupakan harga beli tertinggi dimana investor bersedia untuk membeli saham, sedangkan ask price merupakan harga jual terendah dimana investor bersedia untuk menjual sahamnya. Bid-ask spread merupakan selisih antara ask price dan bid price. Penggunaan bid-ask spread untuk mengukur likuiditas saham beredar pada temuan empirik Conroy, Harris, \& Bennett (1990) dimana terdapat hubungan negatif antara volume perdagangan dan bid-ask spread. 


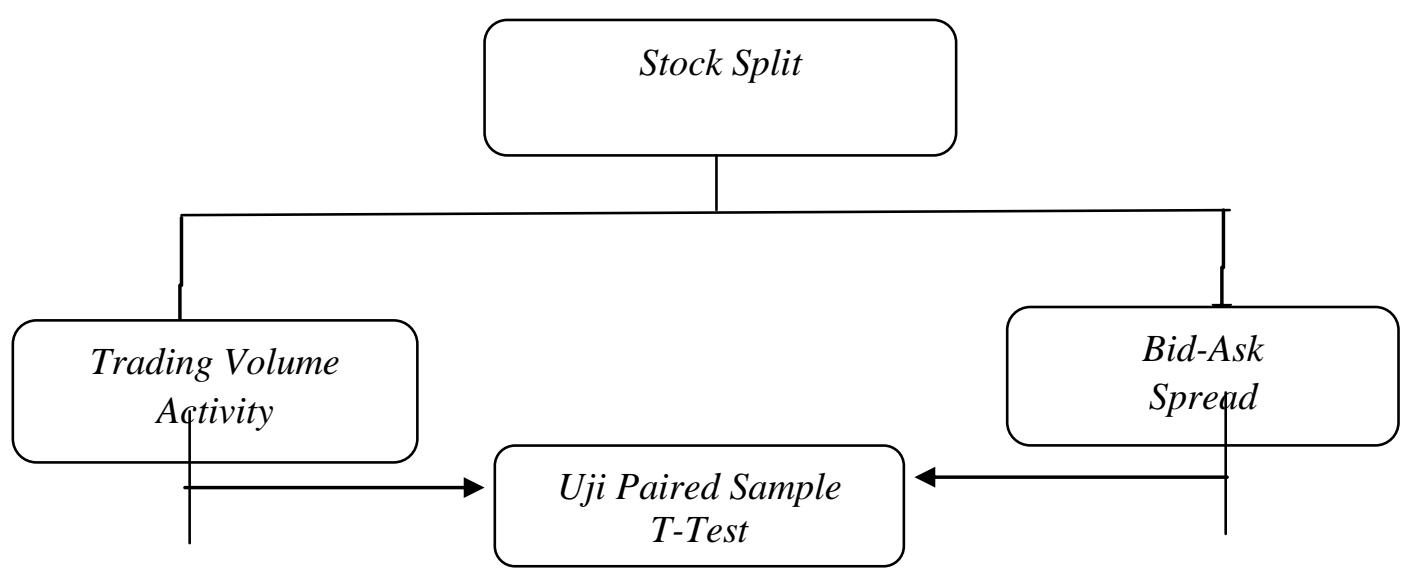

Sumber: Data diolah, 2018

Gambar 1. Kerangka Konseptual

Penelitian yang dilakukan oleh Mulyani \& Purba (2011) menyatakan terdapat perbedaan yang signifikan antara volume perdagangan sebelum dan sesudah peristiwa stock split dimana volume perdagangan meningkat setelah stock split. Hasil ini sesuai dengan trading range theory yang menyatakan bahwa peristiwa stock split akan menyebabkan meningkatnya volume perdagangan akibat harga yang lebih menarik bagi investor. Penelitian ini selaras dengan penelitian Sadikin (2011), penelitian Sidqi dkk. (2017) yang menyatakan terdapat perbedaan volume perdagangan sebelum dan setelah peristiwa stock split yang menyatakan bahwa volume perdagangan mengalami peningkatan setelah stock split. Berdasarkan penelitian tersebut maka hipotesis penelitian yang dirumuskan sebagai berikut.

$\mathrm{H}_{1}$ : Terdapat peningkatan trading volume activity setelah stock split.

Penelitian Rokhman (2009) menyatakan bahwa rata-rata bid-ask spread terdapat penurunan setelah stock split dimana biaya kepemilikan yang ditanggung trader lebih kecil. Penelitian ini selaras dengan penelitian Janiantari (2014) yang menyatakan bahwa terdapat penurunan bid-ask spread setelah stock split. 
Berdasarkan penelitian tersebut, maka hipotesis penelitian yang dirumuskan sebagai berikut.

$\mathrm{H}_{2}$ : Terdapat penurunan bid-ask spread setelah stock split.

\section{METODE PENELITIAN}

Penelitian ini dilakukan pada perusahaan-perusahaan yang melakukan stock split di BEI tahun 2013-2017 yang dapat diakses melalui www.idx.co.id dan www.yahoo.finance.com. Variabel yang diidentifikasi dalam penelitian ini adalah trading volume activity dan bid-ask spread, sedangkan peristiwa pada penelitian ini adalah peristiwa stock split.

Perhitungan TVA dilakukan dengan membandingkan jumlah saham perusahaan yang diperdagangkan dalam suatu periode tertentu dengan keseluruhan jumlah saham yang beredar dari perusahaan tersebut pada kurun waktu yang sama. Perhitungan TVA menurut Foster (1986) sebagai berikut :

Perhitungan TVA masing-masing saham selama periode penelitian dirumuskan sebagai berikut:

$$
\mathrm{TVA}_{\mathrm{i}, \mathrm{t}} \quad=\frac{\sum \text { saham perusa haan iyang diperdagangkan pada waktu ket }}{\sum \text { saham perusahaan i yang beredar pada waktu ke } t} .
$$

Keterangan:

$\mathrm{TVA}_{\mathrm{i}, \mathrm{t}}=$ trading volume activity untuk sekuritas ke-i pada hari ke- $\mathrm{t}$

Menghitung average trading volume activity (ATVA) seluruh saham per hari selama periode peristiwa, yaitu:

ATVA $_{\mathrm{t}}=\frac{\sum_{i=1}^{n} \text { TVA }_{\mathrm{i}, \mathrm{t}}}{\mathrm{n}}$

Keterangan: 
ATVA $_{\mathrm{t}}=$ average trading volume activity pada hari ke- $\mathrm{t}$

$\mathrm{TVA}_{\mathrm{i}, \mathrm{t}}=$ trading volume activity untuk sekuritas ke-i pada hari ke- $\mathrm{t}$

$\mathrm{n} \quad=$ jumlah sekuritas

Bid price merupakan harga beli tertinggi dimana investor bersedia untuk membeli saham, sedangkan ask price merupakan harga jual terendah dimana investor bersedia untuk menjual sahamnya. Bid-ask spread merupakan selisih antara tawaran harga jual terendah dan harga beli tertinggi pada akhir jam perdagangan atas suatu jenis saham di BEI.

Spread menurut Halim \& Hidayat (2000) ditentukan sebagai berikut:

$$
\text { Bid Ask Spread }=\frac{(\text { Ask-Bid }) \ldots . . .}{1 / 2(\text { Ask+Bid })}
$$

Populasi yang dimaksud dalam penelitian ini adalah seluruh perusahaan yang melakukan stock split di BEI. Adapun populasi dalam penelitian ini sebanyak 234 perusahaan. Sampel dalam penelitian ini adalah perusahaanperusahaan yang melakukan stock split tahun 2013-2017. Peneliti mengambil tahun tersebut dikarenakan tahun terkini, digunakan jarak waktu lima tahun ditujukan untuk memperoleh banyak sampel, mengingat setiap tahun tidak semua perusahaan melakukan stock split. Pengambilan sampel dalam penelitian ini dilakukan secara non probability sampling, yaitu dengan menggunakan pendekatan purposive sampling. Hal ini berarti bahwa populasi akan dijadikan sampel penelitian adalah populasi yang memenuhi kriteria sampel tertentu sesuai dengan yang dikehendaki peneliti. Kriteria sampel yang akan digunakan yaitu: (1) Perusahaan tersebut listing di BEI selama tahun 2013-2017; (2) Mengumumkan kebijakan stock split periode 2013-2017; (3) Perusahaan tersebut tidak melakukan 
corporate action lain, seperti right issue, reverse stock, pembagian dividen dan pembagian saham bonus pada saat yang bersamaan dengan tanggal terjadinya stock split; (4) Terdapat data volume transaksi, jumlah saham yang beredar di Bursa Efek Indonesia selama periode penelitian. Berdasarkan kriteria pemilihan sampel diperoleh jumlah sampel sebanyak 53 perusahaan, terdapat 1 perusahaan yang tidak memiliki volume transaksi sebelum dan setelah stock split.

Uji hipotesis digunakan untuk melihat signifikansi rata-rata trading volume activity, dan bid ask spread selama periode stock split. Apabila data berdistribusi normal, maka digunakan uji parametrik paired sample t-test. Uji paired sample ttest digunakan untuk melakukan pengujian terhadap sampel yang saling berhubungan satu sampel dengan sampel lainnya. Uji tersebut sering digunakan ketika menguji model analisis data sebelum dan setelah. Pengujian statistik uji beda rata-rata dua sampel berpasangan dilaksanakan dengan tujuan mengetahui adanya tingkat signifikansi perbedaan trading volume activity dan bid-ask spread sebelum dan setelah stock split. Kriteria uji paired sample t-test ini adalah apabila nilai signifikansi lebih kecil atau sama dengan $0,05($ Sig $\leq 0,05)$ maka hipotesis diterima, sebaliknya apabila signifikansi lebih besar $($ Sig $>0,05)$ maka hipotesis ditolak (Ghozali, 2016). Apabila data berdistribusi tidak normal maka pengujian dilakukan dengan uji nonparametric Wilcoxon Signed Rank Test, namun apabila jumlah observasi cukup besar maka dapat digunakan asumsi Central Limit Theorem yaitu jika $(n>30)$, maka asumsi normalitas dapat diabaikan (Gujarati, 2006). Jadi, hasil pengujian ini dijadikan dasar untuk pengujian hipotesis dengan menggunakan uji parametrik paired sample t-test karena sampel > 30. 


\section{HASIL DAN PEMBAHASAN}

Tabel 1 menjelaskan nilai minimum, maksimum, rata-rata dan deviasi standar TVA pada stock split. Sebelum stock split, nilai minimum sebesar 0,0000000 diperoleh oleh perusahaan Inter Delta Tbk. Nilai maksimum sebesar 0,0082923 diperoleh oleh perusahaan Modernland Realty Tbk. Setelah stock split, nilai minimum sebesar 0,0000003 diperoleh oleh perusahaan Primarindo Asia Infrastructure. Nilai maksimum sebesar 0,0576670 diperoleh oleh perusahaan Sepatu Bata Tbk. Rata-rata TVA sebelum dan setelah stock split mengalami peningkatan sebesar 0,0012186 , ini berarti terjadi peningkatan secara rata-rata pada volume perdagangan saham.

Tabel 1.

Analisis Statistik Deskriptif Trading Volume Activity pada Stock Split

\begin{tabular}{|c|c|c|c|c|c|}
\hline & $\mathrm{N}$ & Minimum & Maksimum & Rata-Rata & Deviasi Standar \\
\hline TVA_sebelum & 53 & 0,0000000 & 0,0082923 & 0,0007127 & 0,0015903 \\
\hline TVA_setelah & 53 & 0,0000003 & 0,0576670 & 0,0019313 & 0,0081329 \\
\hline Valid N & 53 & & & & \\
\hline
\end{tabular}

Tabel 2 menjelaskan nilai minimum, maksimum, rata-rata dan deviasi standar bid-ask spread pada stock split. Sebelum stock split, nilai minimum sebesar 0,0014203 diperoleh oleh perusahaan Indofood CBP Sukses Makmur Tbk. Nilai maksimum sebesar 2,0000000 diperoleh oleh perusahaan Inter Delta Tbk. dan perusahaan Sepatu Bata Tbk. Setelah stock split, nilai minimum sebesar 0,0018115 diperoleh oleh perusahaan Mitra Keluarga Karyasehat Tbk. Nilai maksimum sebesar 1,3403215 diperoleh oleh perusahaan Perdana Bangun Pusaka Tbk. Rata-rata bid-ask spread sebelum dan setelah stock split mengalami penurunan sebesar 0,0872285 , ini berarti terjadi peningkatan secara rata-rata pada likuiditas perdagangan saham. 
Tabel 2.

Analisis Statistik Deskriptif Bid-Ask Spread pada Stock Split

\begin{tabular}{lccccc}
\hline & N & Minimum & Maksimum & Rata-rata & Deviasi Standar \\
\hline BAS_sebelum & 53 & 0,0014203 & 2,0000000 & 0,1563983 & 0,4486653 \\
BAS_setelah & 53 & 0,0018115 & 1,3403215 & 0,0691698 & 0,1852704 \\
Valid N & 53 & & & &
\end{tabular}

Sumber: Data diolah, 2018

Berdasarkan Central Limit Theorem yaitu jika jumlah observasi cukup besar ( $>30)$, maka asumsi normalitas dapat diabaikan (Gujarati, 2006). Jadi, dikarenakan sampel dalam penelitian ini lebih dari $30(n \geq 30)$, sesuai dengan Central Limit Theorem maka data dianggap normal. Pengujian hipotesis yang digunakan dalam penelitian ini yaitu uji parametrik paired sample t-test.

Tabel 3.

Hasil Uji Paired Sample T-test Rata-rata Trading Volume Activity

\begin{tabular}{|c|c|c|c|}
\hline & & & Pair 1 \\
\hline & & & $\begin{array}{l}\text { ATVA Sebelum - } \\
\text { ATVA Sesudah }\end{array}$ \\
\hline \multirow{5}{*}{ Paired Differences } & Mean & & $-0,0012186$ \\
\hline & Std. Deviation & & 0,0076909 \\
\hline & Std. Error Mean & & 0,0010564 \\
\hline & 95\% Confidence Interval & Lower & $-0,0033384$ \\
\hline & of the Difference & Upper & 0,0009012 \\
\hline $\mathrm{T}$ & & & $-1,154$ \\
\hline Df & & & 52 \\
\hline sig. (2-tailed) & & & 0,027 \\
\hline
\end{tabular}

Sumber: Data diolah, 2018

Tabel 3 menunjukkan nilai sig. (2-tailed) 0,027. Nilai ini menyatakan bahwa terjadi peningkatan rata-rata trading volume activity setelah stock split karena sig. (2-tailed) 0,027 lebih kecil dari 0,05. Nilai sig. (2-tailed) tersebut menyatakan bahwa $\mathrm{H}_{1}$ diterima. 
Tabel 4.

Hasil Uji Paired Sample T-test Rata-rata Bid-Ask Spread

\begin{tabular}{|c|c|c|c|}
\hline \multirow[b]{3}{*}{ Paired Differences } & \multirow[b]{3}{*}{ Mean } & \multicolumn{2}{|r|}{ Pair 1} \\
\hline & & & ABAS Sebelum -ABAS Sesudah \\
\hline & & & 0,0872284 \\
\hline & Std. Deviation & & 0,3942194 \\
\hline & Std. Error Mean & & 0,0541502 \\
\hline & 95\% Confidence Interval & Lower & $-0,0214318$ \\
\hline & of the Difference & Upper & 0,1958887 \\
\hline $\mathrm{T}$ & & & 1,611 \\
\hline & & & 52 \\
\hline sig. (2-tailed) & & & 0,033 \\
\hline
\end{tabular}

Sumber: Data diolah, 2018

Tabel 4 menunjukkan nilai sig. (2-tailed) 0,033. Nilai ini menyatakan

bahwa terjadi peningkatan bid-ask spread setelah stock split karena sig. (2-tailed)

0,033 lebih kecil dari 0,05. Nilai sig. (2-tailed) tersebut menyatakan bahwa $\mathrm{H}_{2}$ diterima.

Pengujian TVA pada tabel 3 menunjukan bahwa $\mathrm{H}_{1}$ diterima dimana ini berarti terdapat peningkatan volume perdagangan saham yang menunjukkan bahwa minat investor meningkat setelah stock split akibat harga saham yang lebih menarik sehingga semakin banyak masyarakat yang dapat menjangkau saham tersebut seperti investor berdana kecil.

Penelitian ini sejalan dengan penelitian yang dilakukan oleh Mulyani \& Purba (2011) menyatakan terdapat perbedaan yang signifikan antara volume perdagangan sebelum dan setelah peristiwa stock split dimana volume perdagangan setelah stock split lebih tinggi dibandingan sebelum stock split. Penelitian ini selaras juga dengan penelitian Sadikin (2011), Sidqi dkk. (2017) yang menyatakan terdapat perbedaan volume perdagangan sebelum dan setelah peristiwa stock split yang menyatakan bahwa volume perdagangan mengalami peningkatan setelah stock split. Hasil ini sesuai dengan trading range theory yang 
menyatakan bahwa peristiwa stock split akan menyebabkan meningkatnya volume perdagangan akibat harga yang lebih menarik bagi investor.

Berdasarkan hasil pengujian paired sample t-test yang ditunjukkan pada Tabel 4, diketahui bahwa $\mathrm{H}_{2}$ diterima, yang berarti terjadi penurunan bid-ask spread setelah stock split. Hasil ini menunjukkan bahwa likuiditas saham setelah stock split mengalami peningkatan ditunjukan oleh penurunan rata-rata bid-ask spread setelah stock split. Menurut Kurniawati (2003), penurunan ini disebabkan oleh berkurangnya komponen biaya transaksi sebagai pencerminan bid-ask spread karena harga pasar saham yang menjadi lebih murah sehingga meningkatkan daya tarik investor yang menyebabkan perdagangan menjadi lebih aktif. Kondisi ini memungkinkan pelaku pasar untuk tidak perlu memegang saham terlalu lama sehingga menurunkan biaya pemilikan yang berarti mempersempit bid-ask spread. Harga saham yang lebih rendah setelah dilakukan stock split juga menyebabkan pertemuan antara harga penawaran dan harga permintaan saham (bid-ask spread) semakin kecil. Dampak dari menurunnya spread saham tersebut maka biaya kepemilikan saham yang ditanggung lebih kecil dan saham-saham yang diperdagangkan semakin likuid.

Penelitian ini sejalan dengan penelitian sebelumnya yang dilakukan oleh Rokhman (2009) menyatakan rata-rata bid-ask spread terdapat penurunan bid-ask spread setelah stock split maka biaya kepemilikan yang ditanggung trader lebih kecil. Penelitian ini selaras dengan penelitian Murray (1985), Janiantari (2014) yang menyatakan bahwa terdapat penurunan bid-ask spread setelah stock split. 
Berdasarkan trading range theory, harga saham yang terlalu tinggi berakibat pada kurang aktifnya perdagangan saham tersebut di pasar modal. Sehingga stock split ini dilakukan untuk menurunkan harga saham yang berakibat pada meningkatnya likuiditas saham dalam perdagangan di pasar modal. Minat investor dapat dilihat melalui peningkatan volume perdagangan saham yang diukur menggunakan trading volume activity (TVA) dan likuiditas saham dapat diukur dengan menggunakan bid-ask spread. Bila diukur menggunakan TVA, stock split meningkatkan minat investor karena terjadi peningkatan volume perdagangan saham. Bila diukur menggunakan bid-ask spread, stock split meningkatkan likuiditas perdagangan karena terjadi penurunan bid-ask spread. Implikasi dari penelitian ini adalah harga saham yang terlalu tinggi menyebabkan saham tidak likuid, hal tersebut berkaitan dengan kemampuan tiap-tiap investor yang berbeda-beda, oleh karena itu perusahaan melakukan stock split dalam upaya mengarahkan harga saham pada interval tertentu yang tidak terlalu mahal. Saham yang dinilai terlalu tinggi akan menyebabkan berkurangnya aktivitas saham untuk diperdagangkan, dengan rendahnya harga saham akan memudahkan para investor dari yang memiliki dana kecil untuk lebih mudah masuk karena harga saham yang lebih terjangkau.

Penelitian ini memberikan implikasi bagi para pelaku pasar sebagai pengetahuan dan pertimbangan dalam pengambilan keputusan berinvestasi. Informasi yang relevan dengan kondisi pasar modal merupakan sesuatu yang selalu dicari para pelaku pasar modal dalam upaya melakukan pengambilan keputusan investasi. Namun tidak semua informasi merupakan informasi yang 
berharga, akibatnya para pelaku pasar modal harus secara tepat memilah informasi-informasi yang layak (relevan) dijadikan pertimbangan pengambilan keputusan. Informasi tentang stock split pada penelitian ini menunjukkan adanya peningkatan trading volume activity, dan menunjukkan penurunan bid-ask spread. Dengan kata lain, informasi yang terkandung di dalam peristiwa tersebut mengandung informasi yang mempengaruhi keputusan investor dalam berinvestasi.

\section{SIMPULAN}

Terdapat peningkatan trading volume activity setelah stock split ini berarti minat investor meningkat setelah stock split yang ditunjukkan dengan adanya peningkatan volume perdagangan saham. Penelitian ini sesuai dengan trading range theory yang menyatakan bahwa peristiwa stock split akan menyebabkan meningkatnya volume perdagangan akibat harga yang lebih menarik bagi investor.

Terdapat penurunan bid-ask spread setelah stock split ini berarti likuiditas perdagangan saham mengalami peningkatan setelah stock split. Penurunan bid-ask spread disebabkan oleh berkurangnya komponen biaya transaksi karena harga pasar saham yang menjadi lebih murah sehingga menyebabkan perdagangan menjadi lebih aktif dan saham-saham yang diperdagangkan semakin likuid.

Berdasarkan penelitian ini, beberapa saran yang dapat diberikan bagi peneliti selanjutnya yang ingin melakukan penelitian sejenis dengan 
menggunakan penelitian ini sebagai referensi yaitu, penelitian ini hanya menggunakan trading volume activity dan bid-ask spread untuk mengukur minat investor dan likuiditas perdagangan saham pada stock split. Peneliti selanjutnya diharapkan dapat melakukan penelitian untuk melihat apakah setelah stock split harga saham perusahaan akan terus mengalami peningkatan atau tidak.

Bagi investor diharapkan para investor yang ingin berinvestasi pada perusahaan yang melakukan stock split hendaknya perlu melakukan analisis fundamental perusahaan dan melihat laporan keuangan perusahaan terlebih dahulu. Investor juga perlu mempertimbangkan faktor lain diluar kebijakan perusahaan seperti kondisi pasar yang sedang terjadi, serta faktor-faktor eksternal lainnya seperti faktor ekonomi, faktor politik dalam memutuskan berinvestasi, karena hal ini secara tidak langsung akan mempengaruhi return atau keuntungan yang diperloleh dalam melakukan investasi pada saham.

\section{REFERENSI}

Alon, K., \& Kronlund, M. (2009). Stock Splits-Information or Liquidity. Unpublished Working.

Bechmann, \& Raaballe. (2007). The Difference Between Stock Splits and Stock Dividens: Evidence on the Retained Earning Hypothesis, USA. Journal of Bussiness Finance \& Accounting.

Bhattacharya, \& Dittmar, A. (2001). Costless versus costly signaling in capital markets: theory and Evidence. Indiana/MIT and Michigan University Working Paper.

Bodie, Z., Kane, A., \& Marcus, A. J. (2005). Investment. 6th edition, Mc. Graw Hill.

Brigham, E. F., \& Gapenski. (1994). Financial Management: Theory \& Practice. Orlando: the Drydeen Press. 
Brigham, E. F., \& Houston, J. F. (2014). Dasar-Dasar Manajemen Keuangan. Jakarta: Selemba Empat.

Chakraborty, M. (2012). The Equity Market Around the Ex-Split Date: Evidence from India. Vikalpa, 37(1).

Conroy, D., Harris, M., \& Bennett, R. (1990). The Effect of Stock Split On BidAsk Spread. Journal of Finance, 45.

Copeland, T. E. (1979). Liquidity Changes Following Stock Splits. The Journal Of Finance, 34(1).

Darmadji, T., \& Fakhruddin, H. M. (2012). Pasar Modal di Indonesia: Pendekatan Tanya Jawab. Jakarta: Salemba Empat.

Ford, D. ., H.Nguyen, H., \& T. Nguyen, V. (2012). Analyst Coverage and Market Reaction Around Stock Split Announcement. Applied Financial Economics, Ford, D.AH.

Forjan, J. M., \& McCorry, M. S. (1998). Stock Distribution Announcements and Bid-Ask Spreads. Studies in Economics and Finance, 18(2).

Foster, G. (1986). Financial Statement Analysis. Second Edition. Englewood Cliffs New Jersey. Prentice Hall International.

Ghozali, I. (2016). Aplikasi Analisis Multivariate Dengan SPSS. Semarang: Badan Penerbit Universitas Diponegoro.

Gujarati, D. (2006). Dasar-Dasar Ekonometrika. Jakarta: Erlangga.

Halim, H., \& Hidayat, N. (2000). Studi Empiris Tentang Pengaruh Volume Perdagangan dan Return terhadap Bid-Ask Spread Saham Industri Rokok di Bursa Efek Jakarta Dengan Model Koreksi Kesalahan. Jurnal Riset Akuntansi Indonesia, 3(1), 69-85.

Hartono, J. (2014). Teori Portofolio dan Analisis Investasi. Edisi Kedelapan. Yogyakarta: BPFE

Horner, J., \& Wachowicz, J. M. (1997). Prinsip-Prinsip Manajemen Keuangan. Jakarta: Salemba Empat.

Janiantari, I. G. . (2014). Analisis Perbedaan Bid-Ask Spread dan Abnormal Return Saham sebagai Dampak dari Pengumuman Stock Split. E-Jurnal Akuntansi Universitas Udayana, 2(8), 267-282. 
Khomsiyah, \& Sulistyo. (2001). Faktor Tingkat Kemahalan Harga Saham, Kinerja Keuangan Perusahaan dan Keputusan Pemecahan Saham (Stock Split)No Title. Jurnal Ekonomi Dan Bisnis Indonesia Universitas Gadjah Mada, 16(4).

Kurniawati. (2003). Analisis Kandungan Informasi Stock Split dan Likuiditas Saham : Studi Empiris Pada Non-Syncronas Trading. Jurnal Riset Akuntansi Indonesia, 6(3).

Leung, T. Y., Rui, O. M., \& Wang, S. S. (2005). Jurnal Ekonomi dan Bisnis Indonesia Universitas Gadjah Mada. Jurnal of Financial Economics, 161(2).

Lianawati, N. K. (2015). Reaksi Pasar Terhadap Right Issue di Bursa Efek Indonesia. E-Jurnal Manajemen Universitas Udayana.

Marwata. (2001). Kinerja Keuangan, Harga Saham dan Pemecahan Saham. Jurnal Riset Akuntansi Indonesia, 4(2).

Mason, H. B., \& Shelor, R. M. (1998). Stock Splits: An Instittutional Investor Preference. The Financial Review, 33(4).

Mishra. (2006). The Market Reaction to Stock Split-Evidence from India. International Journal of Theoretical and Applied Finance, 10(2).

Mulatsih, L. S. (2009). Analisis Reaksi Pasar Modal Terhadap Pengumuman Right issue di Bursa Efek Jakarta (BEJ) (Pengamatan Terhadap Return, Abnormal Return, Security Return Variability dan Trading Volume Activity). Wacana UB, 12(4).

Mulyani, D., \& Purba, B. R. (2011). Analisis Perbandingan Harga Saham dan Volume Perdagangan Saham Sebelum dan Sesudah Stock Split, 13(1), 5763.

Murray, D. (1985). Dividend Policy Under Assymetric Information. Journal of Finance, 40.

Pooja. (2013). Stock Split Announcement and Liquidity Effect: Evidence from India. Vilakshan, XIMB Journal, 10(1).

Pramana, A. (2012). AAnalisis Perbandingan Trading Volume Activity dan Abnormal Return Saham Sebelum dan Sesudah Pemecahan Saham. Diponegoro Journal Management, 1(1).

Rokhman, M. T. N. (2009). Analisis Return, Abnormal Return, Aktivitas Volume Perdagangan dan Bid-Ask Spread Saham di Seputar Pengumuman Stock Split. Wacana UB, 12(4), 662-677. 
Sadikin, A. (2011). Analisis Abnormal Return Saham dan Volume Perdagangan Saham, Sebelum dan Sesudah Peristiwa Pemecahan Saham. Jurnal Akuntansi Dan Manajemen Universitas Lambung Mangkurat, 12(April), 2534.

Setociputro, S. (2010). Peningkatan Kinerja Perusahaan Go Public Setelah Stock Split (Studi Empiris di Bursa Efek Indonesia Periode 2004-2008). Skripsi.

Sidqi, F. I., Prabawani, B., \& Sos, S. (2017). Analisis Harga Saham dan Volume Perdagangan Saham Sebelum dan Sesudah Melakukan Stock Split ( Studi Empiris pada Perusahaan Go Public Periode 2010-2015 ). Jurnal Ilmu Administrasi Bisnis Universitas Diponegoro, 6(1).

Trijunanto, E. (2016). Analisis Pengaruh Pemecahan Saham (Stock Split) terhadap Abnormal Return Saham dan Likuiditas Saham pada Perusahaan yang Terdaftar di Bursa Efek Indonesia (BEI) Periode 2011-2015. Jurnal Perbanas, 2(1).

Waelan. (2009). Pengaruh Stock Split terhadap Future Profitability dan Likuiditas Saham. Jurnal Bisnis Dan Kewirausahaan, 5(2).

Waweru, N. ., \& Mwendwa, J. (2012). Stock Split and Their Effect on Share Prices: A Study of Firms Listed on The Nairobi Stock Exchange (NSE). Academy of Accounting and Financial Studies Journal, 16(2).

Yan, J. (2012). Stock Split Decisions: A Synthesis of Theory and Evidence, United Stated. Journal of Applied Finance. 